\title{
Análise exegética e pragmalinguística do Salmo 119, 9-16
}

Orientador: Prof. Leonardo Agostini Fernandes

Pesquisadora: Eliane dos Santos Baia

Fonte: Departamento de Teologia

\section{Introdução}

Rezar a Deus com as palavras de Deus. Rezar as orações que inflamaram os fiéis, no judaísmo e no cristianismo. Rezar como rezou o judeu Jesus de Nazaré. Assim, Judeus e cristãos oraram tendo na mente e no coração, antes de ter o livro, as preces por excelência contidas no Saltério. Estas orações, ao longo dos séculos, inspiraram, tanto no Ocidente como no Oriente, poetas, pintores, músicos, escultores e, principalmente, o fascínio em exegetas e teólogos.

Muito já se escreveu sobre os Salmos! É o Livro do Antigo Testamento mais citado no Novo Testamento. De modo geral, nos Salmos são celebrados o nome do Senhor e seus divinos atributos que glorificam a sua ação na história em benefício do antigo Israel. Neles são evocados vários acontecimentos da vida dos fiéis que suplicam, agradecem, rezam, etc. Os Salmos são orações surgidas, quase que espontaneamente, a partir dos acontecimentos históricos das pessoas e do povo. Por isso, são apropriados e podem ser aplicados às diversas circunstâncias da vida pessoal, comunitária e litúrgica.

Diante dessa motivação, a escolha do S1 119,9-16 deu-se pelo interesse de investigar a linguística extratextual (pragmalinguística, sociolinguística, psicolinguística) para perceber se, por ela, a linguística intratextual se completa. Aplicar as noções da pragmalinguística possibilita uma maior compreensão da relação que existe entre o signo e a experiência vital de quem se aproxima dos Salmos. 


\section{Objetivos}

Obter o conhecimento mais aprofundado sobre os Salmos, visto que foram compostos não apenas para a oração individual, mas, principalmente, para o culto litúrgico (cf. Sl 42,5; 47,2.6-7; 95,1-2.6-7), pois pelos Salmos percebe-se não só o que Deus tem a dizer ao ser humano, mas também o que Ele deseja ouvir do ser humano com as palavras que inspirou.

Pesquisar a linguagem do Salmo 119,9-16, analisando-o e interpretando-o, pelo viés da pragmalinguística, como fonte viva herdada pelo cristianismo até nossos dias e assim verificar se a pesquisa bíblica pode avançar nesta área ainda pouco usada no âmbito acadêmico. 